\title{
Analisis Teknologi Laboratoris Gerabah Dari Situs Leran
}

\author{
Fadhlan S. Intan
}

Keywords: pottery, terracotta, clay, petrography, proto-history

\section{How to Cite:}

Intan, F. S. (2003). Analisis Teknologi Laboratoris Gerabah Dari Situs Leran. Berkala Arkeologi, 23(1), 75-87. https:// doi.org/10.30883/jba.v23i1.862

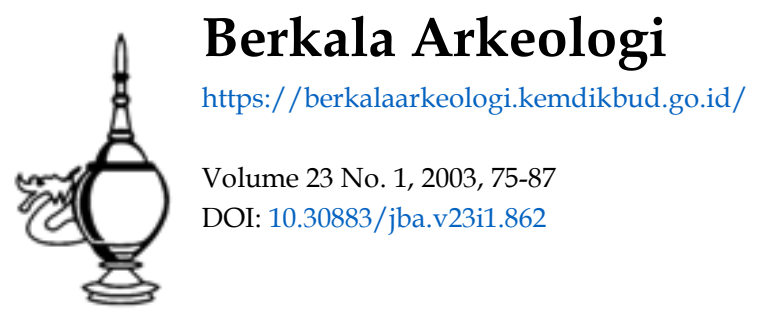

\section{c) (i) (5)}

This work is licensed under a Creative Commons Attribution-NonCommercial-ShareAlike 4.0 International License. 


\section{ANALISIS TEKNOLOGI LABORATORIS GERABAH \\ DARI SITUS LERAN}

\section{Fadhlan S. Intan}

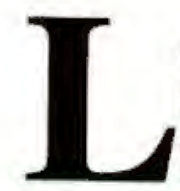

\section{ATAR BELAKANG}

Pemukiman adalah tempat dimana manusia melakukan segala macam kegiatannya. Untuk tetap dapat hidup melangsungkan kehidupannya, manusia secara langsung atau tidak, akan selalu tergantung pada lingkungan alam dan fisik tempatnya hidup. Akan tetapi pada hakekatnya, hubungan manusia dengan lingkungan alam dan fisiknya, tidaklah semata-mata terwujud sebagai hubungan ketergantungan manusia terhadap lingkungannya, tetapi juga terwujud sebagai suatu hubungan dimana manusia mempengaruhi dan merubah lingkungannya. Lingkungan alam dan fisik memberikan tantangan kepada manusia untuk dapat mempertahankan hidup. Sebagai jawaban terhadap tantangan lingkungan, manusia menciptakan kebudayaan (Yacob, 1983, dalam Utomo B.B., 1988). Dengan kebudayaan tadi manusia beradaptasi dengan lingkungannya. Dari lingkungan diperoleh makanan untuk dapat bertahan hidup, dan dari lingkungan pula manusia dapat membuat segala macam peralatan untuk berbagai kebutuhannya.

Olehnya itu, dengan meningkatnya peradaban manusia, maka tingkat kehidupan dan kreativitas manusia dalam memenuhi kebutuhannya akan meningkat pula. Hal ini terlihat pada temuan-temuan dalam setiap penelitian arkeologi, bahan bakunya terbuat dari batu, kayu, dan tanah.

Gerabah merupakan salah satu sisa benda budaya yang paling sering ditemukan dalam penelitian arkeologi. Gerabah dibuat menurut cara-cara tradisional dengan menggunakan tanah liat sebagai bahan bakunya, kemudian dibakar pada temperatur tertentu hingga dianggap matang. Gerabah memegang peranan penting dalam kehidupan masyarakat masa lampau, baik dalam kehidupan sosial maupun dalam kehidupan religius (Soegondho, 1995).

Adanya berbagai bentuk gerabah dan sebaran yang meluas di beberapa situs arkeologi, baik pada masa prasejarah maupun sejarah menunjukan bahwa fungsi gerabah sangat penting dalam kehidupan masyarakat masa lampau. Kajian terhadap aspek teknologis dari gerabah belum banyak dilakukan, sedangkan yang dilakukan selama ini hanya dititikberatkan pada aspek bentuk dan aspek gaya. Melalui kajian teknologis dapat digambarkan kualitas gerabah yang dibuat oleh para pengrajin pada masa lampau, yang pada akhirnya dapat merekonstruksi sejarah budaya Indonesia (Soegondho, 1995). 
Sampel gerabah yang di analisis di laboratorium berasal dari hasil penelitian tim Bidang Arkeologi Islam di Situs Leran, Gresik, Tahun 2001.

Situs Leran termasuk wilayah administratif Desa Leran, Kecamatan Manyar, Kabupaten Gresik, Provinsi Jawa Timur. Secara geografis situs-situs di wilayah Gresik (termasuk situs Leran) terletak diantara dua garis lintang, yaitu 709'45" lintang selatan dan 112038'43" bujur timur, serta tercantum pada peta topografi lembar Karangbinangoen (Sheet54/XL-A\&B); Sidajoe (Sheet54/XXXIX-C\&D); Ojoengpangkah (Sheet 54/XXXIX-A), berskala 1:50.000.

\section{AMPEL ANALISIS}

Analisis teknologis laboratoris gerabah dilaksanakan melalui analisis fisik dan analisis kimia (secara kuantitatif). Analisis fisik bertujuan untuk memperoleh keterangan atau gambaran tentang sifat fisiknya, sedangkan analisis kimia bertujuan menyelidiki banyaknya suatu zat yang terdapat dalam campuran dengan zat lain atau dalam larutan. Metode analisis kimia yang digunakan adalah metode colorimetri, yaitu suatu metode analisis yang didasarkan pada perbandingan warna dengan menggunakan peralatan Soil Analisys Out Fit.

Sampel gerabah yang di analisis berasal dari kotak ekskavasi dan hasil survei. Berdasarkan hasil pemilahan sampel gerabah dari dua jenis kegiatan (ekskavasi dan survei), terpilih delapan lokasi yang dianggap mewakili seluruh temuan gerabah di Situs Leran, Gresik dan sekitarnya, yaitu:

1. Kotak B2U4, spit 4, dengan jumlah 27 buah (213 gram) berupa fragmen tepian dan badan.

2. Kotak B2U4, spit 4, dengan jumlah 58 buah (537 gram) berupa fragmen tepian dan dasar.

3. Kotak S1B1, spit 2, dengan jumlah 107 buah (498 gram) berupa fragmen badan.

4. Kotak B2U7, spit 4, dengan jumlah 53 buah (1300 gram) berupa fragmen tepian dan badan.

5. Kotak S1B1, spit 6, dengan jumlah 120 buah ( 790 gram) berupa fragmen badan.

6. Survei 1141 Banjarsari, dengan jumlah 14 buah ( 850 gram) berupa fragmen tepian.

7. Survei 1042 , dengan jumlah 14 buah ( 60 gram) berupa fragmen tepian dan badan.

8. Survei 1172 Banjarsari, dengan jumlah 15 buah ( 260 gram) berupa fragmen tepian

Jumlah temuan gerabah dari delapan tempat adalah 398 buah dengan berat total 4508 gram. Dalam analisis laboratoris, beberapa sampel harus dihancurkan/dilebur. 
Hasil analisis laboratoris gerabah dari Situs Leran, Gresik, Jawa Timur dengan metode analisis fisik dan analisis kimia adalah sebagai berikut:

\section{Analisis Fisik}

a. Gerabah hasil survei di Banjarsari (kode wilayah survei 1411) berjumlah 14 buah dengan berat 850 gram, berupa fragmen tepian. Berwarna merah (5/6-2,5YR), berat sampel 23,4 gram, tebal $8 \mathrm{~mm}$, dengan kekerasan 3-4 skala Mohs. Berkadar air $0,21 \%$, berat jenis 2,23 dengan porositas $21,43 \%$ serta LOI $8,33 \%$ dan daya serap air 10,89\%. Komposisi bahan baku utama (lempung) $60 \%$, bahan baku tambahan (pasir) 40\%, dengan ukuran butir lempung 0,0168-0,0890 mm dan pasir berukuran butir 1,1250-1,3750 mm. Komposisi mineral adalah kuarsa, hornblende, biotit, plagioklas, piroksen, oksida besi, dan lempung, sedangkan komposisi non mineral adalah fragmen batuan beku. Tingkat pembakaran gerabah tersebut adalah $500^{\circ}-600^{\circ}$ Celcius.

b. Gerabah hasil survei di wilayah 1042 berjumlah 14 buah dengan berat 60 gram, berupa fragmen tepian dan badan. Berwarna pink keputihan $(8 / 2-5 Y R)$, berat sampel 18,44 gram, tebal $6 \mathrm{~mm}$, dengan kekerasan 2-3 skala Mohs. Berkadar air $6,67 \%$, berat jenis 2,47 dengan porositas $27,25 \%$ serta LOI $12,5 \%$ dan daya serap air $13,12 \%$. Komposisi bahan baku utama (lempung) $90 \%$, bahan baku tambahan (pasir) 10\%, dengan ukuran butir lempung 0,0039-0,0078 $\mathrm{mm}$ dan pasir berukuran butir 0,0156-0,0208 mm. Komposisi mineral adalah kuarsa, plagioklas, oligoklas, olivin, dan lempung, sedangkan komposisi non mineral tidak ada. Tingkat pembakaran gerabah tersebut adalah $600^{\circ}$ Celcius.

c. Gerabah hasil ekskavasi di kotak B2U4, spit 4 berjumlah 27 buah dengan berat 213 gram, berupa fragmen tepian dan badan. Berwarna abu-abu muda (7/1-5YR), berat sampel 26,52 gram, tebal $7 \mathrm{~mm}$, dengan kekerasan 4 skala Mohs. Berkadar air $1,96 \%$, berat jenis 2,36 dengan porositas $22,04 \%$ serta LOI $6,25 \%$ dan daya serap air $10,08 \%$. Komposisi bahan baku utama (lempung) $80 \%$, bahan baku tambahan (pasir) 20\%, dengan ukuran butir lempung 0,0039-0,0078 mm dan pasir berukuran butir 0,0156-0,0208 $\mathrm{mm}$. Komposisi mineral adalah kuarsa, plagioklas, oligoklas, olivin, dan lempung, sedangkan komposisi non mineral tidak ada. Tingkat pembakaran gerabah tersebut adalah $600^{\circ}$ Celcius.

d. Gerabah hasil ekskavasi di kotak B2U4, spit 4 berjumlah 58 buah dengan berat 537 gram, berupa fragmen tepian dan dasar. Berwarna pink (7/4-5YR), berat sampel 16,12 gram, tebal $8 \mathrm{~mm}$, dengan kekerasan 3-4 skala Mohs. Berkadar air $3,10 \%$, berat jenis 2,51 dengan porositas $31,64 \%$ serta LOI $11,11 \%$ dan daya serap air $15,52 \%$. Komposisi bahan baku utama (lempung) $70 \%$, bahan baku tambahan (pasir) 30\%, dengan ukuran butir lempung 0,0039-0,0078 $\mathrm{mm}$ dan pasir berukuran butir 0,0156-0,0208 $\mathrm{mm}$. Komposisi mineral adalah kuarsa, 
hornblende, biotit, plagioklas, piroksen, dan lempung, sedangkan komposisi non mineral tidak ada. Tingkat pembakaran gerabah tersebut adalah $600^{\circ}$ Celcius.

e. Gerabah hasil survei di Banjarsari (kode wilayah survei 1172) berjumlah 15 buah dengan berat 260 gram, berupa fragmen tepian. Berwarna merah kecoklatan (5/42,5YR), berat sampel 15,82 gram, tebal $8 \mathrm{~mm}$, dengan kekerasan 3-4 skala Mohs. Berkadar air 3,85\%, berat jenis 2,24 dengan porositas $19,73 \%$ serta LOI $16,66 \%$ dan daya serap air $9,89 \%$. Komposisi bahan baku utama (lempung) $60 \%$, bahan baku tambahan (pasir) 40\%, dengan ukuran butir lempung 0,0156-0,0208 $\mathrm{mm}$ dan pasir berukuran butir 0,6250-0,8750 mm. Komposisi mineral adalah kuarsa, hornblende, biotit, plagioklas, piroksen, oksida besi, dan lempung, sedangkan komposisi non mineral adalah fragmen batuan beku. Tingkat pembakaran gerabah tersebut adalah $500^{\circ}-600^{\circ}$ Celcius.

f. Gerabah hasil ekskavasi di kotak S1B1, spit 2 berjumlah 107 buah dengan berat 498 gram, berupa fragmen badan. Berwarna merah muda (7/6-2,5YR), berat sampel 9,58 gram, tebal $4 \mathrm{~mm}$, dengan kekerasan 3 skala Mohs. Berkadar air $1,67 \%$, berat jenis 2,42 dengan porositas $30,21 \%$ serta LOI 3,50\% dan daya serap air $15,13 \%$. Komposisi bahan baku utama (lempung) $85 \%$, bahan baku tambahan (pasir) 15\%, dengan ukuran butir lempung 0,0078-0,0156 $\mathrm{mm}$ dan pasir berukuran butir 0,2500-0,1250 mm. Komposisi mineral adalah kuarsa, homblende, piroksen, dan lempung, sedangkan komposisi non mineral adalah fragmen batuan beku. Tingkat pembakaran gerabah tersebut adalah $600^{\circ}$ Celcius.

g. Gerabah hasil ekskavasi di kotak B2U7, spit 4 berjumlah 53 buah dengan berat 1300 gram, berupa fragmen tepian dan badan. Berwarna merah muda kecoklatan (7/3-7,5YR), berat sampel 45,67 gram, tebal 9-12 mm, dengan kekerasan 4 skala Mohs. Berkadar air $1,75 \%$, berat jenis 2,3 dengan porositas $19,61 \%$ serta LOI $1,40 \%$ dan daya serap air $9,57 \%$. Komposisi bahan baku utama (lempung) $52 \%$, bahan baku tambahan (pasir) 48\%, dengan ukuran butir lempung 0,0168-0,0890 $\mathrm{mm}$ dan pasir berukuran butir 1,1250-1,3750 mm. Komposisi mineral adalah kuarsa, hormblende, biotit, piroksen, olivin, plagioklas, dan lempung, sedangkan komposisi non mineral tidak ada. Tingkat pembakaran gerabah tersebut adalah $600^{\circ}$ Celcius.

h. Gerabah hasil ekskavasi di kotak S1B1, spit 6 berjumlah 120 buah dengan berat 790 gram, berupa fragmen badan. Berwarna merah muda kecoklatan (6/4-2,5YR), berat sampel 26,78 gram, tebal 6-8 mm, dengan kekerasan 3 skala Mohs. Berkadar air 5,63\%, berat jenis 2,48 dengan porositas $24,9 \%$ serta LOI $2,43 \%$ dan daya serap air $11,48 \%$. Komposisi bahan baku utama (lempung) $60 \%$, bahan baku tambahan (pasir) 40\%, dengan ukuran butir lempung 0,0168-0,0890 mm dan pasir berukuran butir 1,1250-1,3750 mm. Komposisi mineral adalah kuarsa, hornblende, biotit, plagioklas, piroksen, oksida besi dan lempung, sedangkan komposisi non mineral adalah fragmen batuan beku. Tingkat pembakaran gerabah tersebut adalah $600^{\circ}$ Celcius. 


\section{Analisis Kimia}

a. Gerabah hasil survei di Banjarsari (kode wilayah survei 1411) berjumlah 14 buah dengan berat 850 gram, berupa fragmen tepian. Mengandung silikat ( $\mathrm{SiO} 2) 75 \%$, besi (Fe) 1,74\%, kapur (CaCO3) $8 \%$, Magnesium (Mg) 2\%, hilang bakar (LOI) $8,33 \%$, dan unsur-unsur lain $4,93 \%$.

b. Gerabah hasil survei di wilayah 1042 berjumlah 14 buah dengan berat 60 gram, berupa fragmen tepian dan badan. Mengandung silikat (SiO2) 67\%, besi (Fe) $1,8 \%$, kapur (CaCO3) 8\%, Magnesium (Mg) 4\%, hilang bakar (LOI) 12,5\%, dan unsur-unsur lain $6,7 \%$.

c. Gerabah hasil ekskavasi di kotak B2U4, spit 4 berjumlah 27 buah dengan berat 213 gram, berupa fragmen tepian dan badan. Mengandung silikat (SiO2) 69\%, besi $(\mathrm{Fe}) 0,45 \%$, kapur (CaCO3) $10 \%$, Magnesium $(\mathrm{Mg}) 6 \%$, hilang bakar (LOI) $6,25 \%$, dan unsur-unsur lain $8,3 \%$.

d. Gerabah hasil ekskavasi di kotak B2U4, spit 4 berjumlah 58 buah dengan berat 537 gram, berupa fragmen tepian dan dasar. Mengandung silikat (SiO2) 71\%, besi (Fe) $2,97 \%$, kapur (CaCO3) $8 \%$, Magnesium (Mg) $4 \%$, hilang bakar (LOI) 11,1 I \%, dan unsur-unsur lain $2,92 \%$.

e. Gerabah hasil survei di Banjarsari (kode wilayah survei 1172) berjumlah 15 buah dengan berat 260 gram, berupa fragmen tepian. Mengandung silikat (SiO2) 59\%, besi (Fe) 3,78\%, kapur (CaCO3) 12\%, Magnesium (Mg) 6\%, hilang bakar (LOI) $16,66 \%$, dan unsur-unsur lain $2,56 \%$.

f. Gerabah hasil ekskavasi di kotak S1B1, spit 2 berjumlah 107 buah dengan berat 498 gram, berupa fragmen badan. Mengandung silikat ( $\mathrm{SiO} 2) 67 \%$, besi ( $\mathrm{Fe}$ ) 4,62\%, kapur (CaCO3) 12\%, Magnesium (Mg) 6\%, hilang bakar (LOI) 3,50\%, dan unsur-unsur lain $6,88 \%$.

g. Gerabah hasil ekskavasi di kotak B2U7, spit 4 berjumlah 53 buah dengan berat 1300 gram, berupa fragmen tepian dan badan. Mengandung silikat (SiO2) 62\%, besi (Fe) 4,62\%, kapur (CaCO3) 12\%, Magnesium (Mg) $8 \%$, hilang bakar (LOI) $1,40 \%$, dan unsur-unsur lain $11,98 \%$.

h. Gerabah hasil ekskavasi di kotak S1B1, spit 6 berjumlah 120 buah dengan berat 790 gram, berupa fragmen badan. Mengandung silikat (SiO2) 69\%, besi (Fe) $3,78 \%$, kapur (CaCO3) 10\%, Magnesium (Mg) $8 \%$, hilang bakar (LOI) 2,43\%, dan unsur-unsur lain $6,79 \%$.

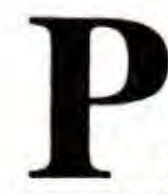

\section{EMBAHASAN}

Dari analisis fisik, didapatkan data-data sebagai berikut, kekerasan (hardness) gerabah adalah 2-4 Skala Mohs, dengan berat jenis 2,23-2,51 serta porositas $19,61 \%-31,64 \%$ dan daya serap air $9,57 \%-15,52 \%$. Berkadar air $0,21 \%-6,67 \%$ dengan LOI 1,40\%-16,66\%. Perbandingan komposisi bahan baku, yaitu bahan baku utama (lempung) 52\%-90\%, sedangkan bahan baku tambahan (pasir) $10 \%-48 \%$, Lempung 
sebagai bahan baku utama berukuran butir $0,0039 \mathrm{~mm}-0,0890 \mathrm{~mm}$, sedangkan pasir sebagai bahan baku tambahan berukuran butir 0,0156 mm -1,3750 mm. Komposisi mineral adalah kuarsa, hornblende, biotit, plagioklas, piroksin, oksida besi, oligoklas, olivin, dan lempung, sedangkan non mineral adalah fragmen batuan beku. Secara umum gerabah-gerabah ini mempunyai tingkat pembakaran antara $500^{\circ}-600^{\circ}$ Celcius.

Dari hasil analisis kimia, diperoleh 4 unsur kimia, yaitu $\mathrm{Si}, \mathrm{Fe}, \mathrm{Ca}$, dan $\mathrm{Mg}$. dari keempat unsur tersebut, maka unsur Si menduduki tempat pertama dengan prosentase $59-75 \%$, disusul $\mathrm{Ca} 8-12 \%, \mathrm{Mg} 2-8 \%$, dan Fe 0,45-4,62\%. Dari keempat unsur tersebut, tidak dimasukkan hilang bakar (LOI) sebesar 1,40-16,66\%, dan unsur-unsur lain yang tidak terdeteksi sebesar 2,56-11,98\%.

Data-data hasil analisis gerabah dari Situs Leran, Gresik, Jawa Timur, dapat dijelaskan sebagai berikut:

Kenampakan warna gerabah-gerabah dari situs Leran adalah merah, merah muda kecoklatan, merah kecoklatan, pink, pink keputihan, dan abu-abu muda. Adanya warna kemerahan ini disebabkan adanya kandungan oksida besi dan piroksen pada bahan baku, sedangkan yang berwarna pink keputihan hingga abu-abu muda disebabkan karena mineralnya didominasi oleh mineral felsic.

Kekerasan fragmen gerabah termasuk dalam kategori tingkat lunak, dengan hasil pengukuran adalah 2-4 skala Mohs. Melihat data hasil pengukuran kekerasan, yang apabila dibandingkan dengan hasil analisis kimia (untuk penentuan unsur Si), maka terlihat adanya perbedaan. Tingginya prosentase unsur Si $(59-75 \%)$ dibanding dengan unsur-unsur lain, seharusnya ikut mempengaruhi tingkat kekerasan gerabah, seperti yang dijelaskan oleh Shepard (1965) bahwa tingkat kekerasan suatu gerabah, dipengaruhi oleh kandungan Silika $\left(\mathrm{SiO}_{2}\right)$. Apabila suatu gerabah banyak mengandung silika, maka gerabah tersebut akan menjadi keras, hal ini disebabkan karena unsur silika akan mengisi ruang kosong, yang terbentuk diantara butiran tanah dengan partikel lain yang ditinggalkan oleh air sewaktu pembakaran gerabah berlangsung. Perlu dijelaskan, bahwa tingkat kekerasan gerabah Situs Leran yang cukup rendah, disebabkan karena, gerabah-gerabah tersebut cukup lama berada pada suatu lingkungan yang berair, dimana mineral yang pertama terbentuk (menurut Bowens reaction series) akan cepat melapuk, sehingga ikatan-ikatan antar mineral juga akan menjadi lemah, yang pada akhirnya akan mempengaruhi tingkat kekerasan gerabah tersebut.

Kadar air, dan LOI termasuk dalam kategori rendah dengan hasil pengukuran $0,21 \%$ hingga $6,67 \%$, untuk LOI atau sering disebut kandungan air kimiawi, juga termasuk dalam kategori rendah dengan hasil pengukuran $1,40 \%$ hingga $16,66 \%$. Kadar air yang dimaksud disini adalah air yang terikat secara mekanis, yang dapat dihilangkan 
melalui pemanasan pada suhu $100^{\circ} \mathrm{C}$, sedangkan kandungan air kimiawi dapat dihilangkan dengan pemanasan tingkat tinggi. Dengan melihat hasil pengukuran kadar air dan LOI, maka gerabah-gerabah dari Situs Leran ini, dikategorikan sebagai gerabah yang baik, karena secara tidak langsung, gerabah-gerabah ini selalu dalam keadaan kering, atau kandungan air yang ada, dapat menguap lebih cepat.

Berat jenis gerabah dari situs Leran, yang dalam kondisi normal dapat dikatakan ringan, mengingat hasil penentuan berat jenisnya berkisar antara 2,23 hingga 2,51. Menurut Sudiono (2000), suatu benda dapat dikatakan ringan jika memiliki berat jenis kurang dari 2,7 dan dapat dinyatakan berat jika memiliki berat jenis lebih dari 2,7. Kondisi berat jenis gerabah berpengaruh pada bobotnya. Apabila gerabah tersebut berukuran besar, dengan berat jenis yang ringan, maka bobot gerabah tersebut akan menjadi ringan, sehingga mudah untuk dibawa dari satu tempat ke tempat lain.

Porositas termasuk dalam kategori rendah-sedang dengan hasil pengukuran 19,61\% hingga 31,64\%. Apabila gerabah-gerabah situs Leran digunakan sebagai wadah untuk benda-benda cair, maka porositas dengan kategori seperti diatas, sangat baik, sehingga dapat dikatakan, gerabah-gerabah tersebut, termasuk gerabah dengan kualitas yang baik. Apabila porositas rendah-sedang, maka benda cair di dalam gerabah akan bertahan lama atau tidak mudah menguap, karena kondisi gerabah dalam keadaan padat atau masif. Sehingga dapat dikatakan bahwa porositas akan sangat berpengaruh terhadap ikatan komponen yang membentuk gerabah.

Daya serap air termasuk dalam kategori rendah dengan hasil pengukuran $9,57 \%$ hingga $15,52 \%$. Angka-angka ini memperlihatkan bahwa kandungan air yang dapat diserap oleh gerabah Situs Leran termasuk kecil. Daya serap air berpengaruh pada penggunaan praktis, baik bersifat keseharian, maupun untuk suatu acara-acara. Sehingga dapat pula dikatakan bahwa, daya serap air sangat berpengaruh pada kualitas gerabah.

Pengamatan unsur mineral dan kenampakan fisik warna fragmen gerabah, maka bahan baku utama dan bahan tambahan berasal dari jenis lempung, napal, batupasir dan batupasir tufaan dengan ukuran butir very fine silt hingga fine silt dari kelompok batuan sedimen. Jenis-jenis batuan tersebut, tersebar luas di wilayah Gresik, yaitu di Kampung Pesantren, Leran, Kampung Banjarsari, Kampung Pegandeng, Kampung Doho, Kampung Sidorejo, dan Kampung Kalisat. Untuk menentukan lokasi bahan baku dan jenis bahan baku utama, dari gerabah-gerabah situs Leran, perlu dilakukan analisis sedimentologi, dengan sampel-sampel aluvial yang telah disebutkan diatas. Dari analisis sedimentologi dapat diketahui jenis aluvial yang digunakan sebagai bahan baku utama. 
Ukuran butir bahan baku utama, termasuk dalam jenis Lempung (clay) yang mempunyai sifat kohesi yaitu butirannya mempunyai tendensi yang saling melekat satu sama lain, yang memungkinkan dilakukan perubahan bentuk tanpa mengalami perubahan isi, atau kembali kebentuk semula.

Tingkat pembakaran gerabah dari situs Leran adalah $500^{\circ}-600^{\circ}$ Celcius. Dengan melihat tingkat pembakaran dari delapan sampel gerabah yang hanya mencapai $500^{\circ}$ $600^{\circ}$ Celcius, maka gerabah-gerabah Situs Leran, dibakar pada udara terbuka (open air baked). Sewaktu dilakukan uji ulang bakar diatas pada $800^{\circ}$ Celcius, ternyata fragmen-fragmen gerabah tersebut menjadi lebih keras dan kuat.

Pada pengamatan komposisi mineral, maka mineral kuarsa dan lempung yang menduduki peringkat pertama dalam arti bahwa kedua mineral tersebut ditemukan pada delapan sampel gerabah, disusul plagioklas yang ditemukan hanya pada tujuh sampel gerabah. Piroksin dan hornblende ditemukan pada enam sampel gerabah, biotit ditemukan pada 5 sampel gerabah, oksida besi ditemukan pada 3 sampel gerabah, olivin ditemukan pada 3 sampel gerabah, sedangkan oligoklas hanya ditemukan pada dua sampel gerabah. Sedangkan untuk komposisi non mineral yang berupa fragmen batuan beku ditemukan pada empat sampel gerabah.

Dari hasil analisis kimia, diperoleh 4 unsur kimia, yaitu $\mathrm{Si}, \mathrm{Fe}, \mathrm{Ca}$, dan $\mathrm{Mg}$. dari keempat unsur tersebut, maka unsur $\mathrm{Si}$ menduduki tempat pertama dengan prosentase $59-75 \%$, disusul $\mathrm{Ca} 8-12 \%$, $\mathrm{Mg} 2-8 \%$, dan Fe 0,45-4,62\%. Dari keempat unsur tersebut, tidak dimasukkan hilang bakar (LOI) sebesar 1,40-16,66\%, dan unsur-unsur lain yang tidak terdeteksi sebesar 2,56-11,98\%.

Unsur-unsur tersebut diatas, ditemukan pada mineral-mineral (kuarsa, hornblende, biotit, plagioklas, piroksin, oksida besi, oligoklas, olivin, dan lempung), yang terdapat pada sembilan sampel, sebagai berikut:

- Unsur Fe. Unsur ini ditemukan pada mineral hematit $(70 \%)$, olivin $(44,44 \%)$, hornblende $(21,43 \%)$, biotit $(20,93 \%)$, dan piroksin $(15,73 \%)$.

- Unsur Si. Unsur ini ditemukan pada mineral kuarsa $(46,7 \%)$, plagioklas $(32,08 \%)$, oligoklas $(27,81 \%)$, hornblende $(17,19 \%)$, piroksin $(15,73 \%)$, olivin $(11,13 \%)$, dan biotit $(5,27 \%)$.

- Unsur Mg. Unsur ini ditemukan pada mineral olivin (19,04\%), hornblende $(9,18 \%)$, biotit $(8,97 \%)$, dan piroksin $(6,74 \%)$.

- Unsur Ca. Unsur ini ditemukan pada mineral oligoklas $(13,24 \%)$, piroksin $(11,24 \%)$, dan homblende $(6,12 \%)$.

Uraian diatas telah memberikan suatu interpretasi bahwa hasil analisis fisik dan analisis kimia telah terdapat suatu kesamaan hasil analisis. 
Dalam analisis kimia unsur Fe menduduki rangking pertama, disusul $\mathrm{Si}, \mathrm{Mg}$, dan $\mathrm{Ca}$. apabila hasil analisis kimia disebandingkan dengan kandungan unsur kimia dari setiap unsur-unsur kimia yang terdapat pada mineral-mineral yang ditemukan pada gerabah, maka yang menduduki rangking pertama adalah Fe $(172,53 \%)$, disusul Si $(155,91 \%)$, $\mathrm{Mg}(43,93 \%)$, dan Ca $(30,6 \%)$. Berdasarkan kandungan ke empat unsur pada mineralmineral yang ditemukan pada gerabah, maka prosentasenya adalah $\mathrm{Fe}(43 \%), \mathrm{Si}$ (39\%), $\mathrm{Mg}(10 \%)$, dan $\mathrm{Ca}(8 \%)$.

Untuk menjawab permasalahan tersebut, maka perlu diketahui mineral-mineral yang tahan terhadap pelapukan dengan menggunakan Diagram Bown's Reaction Series (William, Turner, Gilbert, 1954), misalnya mineral yang paling tahan terhadap pelapukan adalah kuarsa $\left(\mathrm{SiO}_{2}\right)$, sehingga mineral ini ditemukan pada semua jenis batuan (beku, sedimen, metamorf). Sedangkan mineral yang tidak tahan terhadap pelapukan adalah mineral-mineral yang pertama menghablur, contohnya mineral olivin (discontinious series) dan mineral anorthite (continious series). Mineral-mineral yang ditemukan pada gerabah tersebut, dapat disusun berdasarkan Diagram Bown's Reaction Series, sebagai berikut: olivin, piroksin, plagioklas, oligoklas, hornblende, biotit dan kuarsa.

Suatu hal yang menarik, apabila data-data hasil analisis fisik gerabah dari situs Leran ini disebandingkan dengan yang diajukan oleh Soegondho, (1993), maka gerabahgerabah dari situs Leran, termasuk pada:

- Kualitas sedang, didasarkan pada berat jenis (2,23-2,51)

- Kualitas baik, berdasarkan pada porositas $(19,61 \%-31,64 \%)$

- Kualitas buruk-baik, berdasarkan pada kekerasan (2-4 Skala Mohs)

ACUAN PENENTU KUALITAS TEMBIKAR PLAWANGAN \& GILIMANUK (Soegondho, 1993:337)

\begin{tabular}{|l|c|c|c|}
\hline PENGUKURAN & KUALITAS BURUK & $\begin{array}{c}\text { KUALITAS } \\
\text { SEDANG }\end{array}$ & KUALITAS BAIK \\
\hline Berat Jenis & $1-1,90 \mathrm{~g} / \mathrm{cm} 3$ & $2-3,5 \mathrm{~g} / \mathrm{cm} 3$ & $>3,5 \mathrm{~g} / \mathrm{cm} 3$ \\
\hline Kekerasan & $<3 \mathrm{Mohs}$ & $3-3,5 \mathrm{Mohs}$ & $>3,5 \mathrm{Mohs}$ \\
\hline Porositas & $>50 \%$ & $40-50 \%$ & $<40 \%$ \\
\hline
\end{tabular}

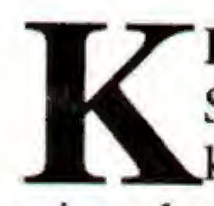

\section{ESIMPULAN}

Secara umum gerabah dari Situs Leran, Gresik, Jawa Timur, termasuk dalam mineral mafic dan mineral felsic, yang sangat berpengaruh terhadap warna-warna gerabah. Tingkat kekerasan yang rendah (2-4 Skala Mohs), lebih banyak disebabkan oleh faktor lingkungan tempat gerabah-gerabah tersebut ditemukan, yaitu berada pada 
suatu lingkungan yang berair, sehingga berpengaruh terhadap ikatan-ikatan antar mineral, yang pada akhirnya akan mempengaruhi tingkat kekerasan gerabah tersebut.

Kadar air $(0,21 \%-6,67 \%)$ dan LOI $(1,40 \%-16,66 \%)$ termasuk dalam kategori rendah, sehingga gerabah-gerabah dari Situs Leran ini, dapat dikategorikan sebagai gerabah yang juga cukup baik, karena secara tidak langsung, gerabah-gerabah ini selalu dalam keadaan kering, atau kandungan air yang ada, dapat menguap lebih cepat.

Berat jenis gerabah dari situs Leran, yang dalam kondisi normal dapat dikatakan ringan, mengingat hasil penentuan berat jenisnya berkisar antara 2,23-2,51. Kondisi berat jenis gerabah berpengaruh pada bobotnya. Apabila gerabah tersebut berukuran besar, dengan berat jenis yang ringan, maka bobot gerabah tersebut akan menjadi ringan, sehingga mudah untuk dibawa dari satu tempat ke tempat lain.

Porositas termasuk dalam kategori rendah-sedang (19,61\%-31,64\%). Apabila porositas rendah-sedang, maka benda cair di dalam gerabah akan bertahan lama atau tidak mudah menguap, karena kondisi gerabah dalam keadaan padat atau masif, sebab porositas akan sangat berpengaruh terhadap ikatan komponen yang membentuk gerabah. Olehnya itu, berdasarkan data porositas yang ada, maka gerabah-gerabah situs Leran termasuk pada gerabah yang baik.

Daya serap air termasuk dalam kategori rendah $(9,57 \%-15,52 \%)$. Data ini memperlihatkan bahwa kandungan air yang dapat diserap oleh gerabah Situs Leran termasuk kecil. Daya serap air sangat berpengaruh pada kualitas gerabah. Dengan kategori ini, maka gerabah tersebut termasuk gerabah yang baik.

Komposisi mineral dan kenampakan fisik warna fragmen gerabah, maka bahan baku utama dan bahan tambahan berasal dari jenis lempung, napal, batupasir dan batupasir tufaan dengan ukuran butir very fine silt hingga fine silt dari kelompok batuan sedimen.

Tingkat pembakaran gerabah dari Situs Leran adalah $500^{\circ}-600^{\circ}$ Celcius. Dengan melihat tingkat pembakaran dari delapan sampel gerabah yang hanya mencapai $500^{\circ}$ $600^{\circ}$ Celcius, maka gerabah-gerabah Situs Leran, dibakar pada udara terbuka (open air baked).

Dari Hasil analisis kimia, diperoleh 4 unsur kimia, yaitu $\mathrm{Si}, \mathrm{Fe}, \mathrm{Ca}$, dan $\mathrm{Mg}$. dari keempat unsur tersebut, maka unsur Si menduduki tempat pertama dengan prosentase $59-75 \%$, disusul $\mathrm{Ca} 8-12 \%, \mathrm{Mg} 2-8 \%$, dan Fe 0,45-4,62\%. Dari keempat unsur tersebut, tidak dimasukkan hilang bakar (LOI) sebesar 1,40-16,66\%, dan unsur-unsur lain yang tidak terdeteksi sebesar 2,56-11,98\%. 
Dari mineral-mineral tersebut, maka mineral kuarsa dan lempung yang menduduki peringkat pertama dalam arti bahwa kedua mineral tersebut ditemukan pada delapan sampel gerabah, disusul plagioklas yang ditemuka hanya pada tujuh sampel gerabah. Piroksin dan hornblende ditemukan pada enam sampel gerabah, biotit ditemukan pada 5 sampel gerabah, oksida besi ditemukan pada 3 sampel gerabah, sedangkan oligoklas dan olivin hanya ditemukan pada dua sampel gerabah. Untuk komposisi non mineral berupa fragmen batuan beku ditemukan pada empat sampel gerabah.

Dalam analisis unsur kimia, terdapat kekurangan atau kelemahan, sebab masih banyak unsur yang harus dideteksi, misalnya $\mathrm{Na}, \mathrm{Al}$, dan lain-lain sebagainya. Sehingga data analisis kimia ini, belum memberikan banyak interpretasi dalam menunjang hasil analisis fisik.

Mengacu pada Soegondho, (1993), maka gerabah-gerabah dari Situs Leran, termasuk pada 1) Kualitas sedang, didasarkan pada berat jenis $(2,23-2,51)$; 2) Kualitas baik, berdasarkan pada porositas $(19,61 \%-31,64 \%)$ dan; 3) Kualitas buruk-baik, berdasarkan pada kekerasan (2-4 Skala Mohs).

Secara umum, dapat disimpulkan bahwa gerabah dari Situs Leran, Gresik, Jawa Timur, mempunyai kualitas yang termasuk dalam kategori baik. 


\section{KEPUSTAKAAN}

Eriawati Yusmaini dan Intan S. Fadhlan M., 1998 Kendi Tembikar Situs Gedungkarya: Gambaran Tingkat Keterampilan Penganjun Lokal. Siddhayatra, Jurnal Arkeologi No. 2/III/Nop/1998, Balar Palembang.

Eriawati Yusmaini, Intan S. Fadhlan M., Lelono Harry, 2001 Studi Etnoarkeologi: Pola Tata Kerja dan Tata Ruang Kerja Pengrajin Tembikar di Kec. Bayat, Kab. Kalten, Prov. Jawa Tengah. LPA Bidang Program, Sub Bidang Arkeometri, Puslit Arkeologi.

Intan S. Fadhlan M., 1996 Analisis-Analisis Teknologi Gerabah Dan Sedimentologi Situs-Situs Prasejarah Gunung Sewu, Jatim, Jateng, D.I.Y. LPA Bidang Arkeometri, Puslit Arkenas.

Intan S. Fadhlan M., 1996 Industri Gerabah Di Kolo-Kolo, Selayar. Majalah Kebudayaan No.12 Thn-VI 1996/ 1997.

Intan S. Fadhlan M., 2001 Analisis Laboratoris Gerabah Dari Situs Leran, Kab. Gresik, Prop. Jawa Timur. Laporan Analisis Subbidang Arkeometri, Bidang Program. P3AJ Puslit Arkeologi.

Kraus, Hunt, Ramsdell, 1959 Mineralogy, An Introduction to the Study of Minerals and Crystals. McGraw-Hill Book Company, Inc. New York, Toronto, London, Kogakusha Company, Ltd. Tokyo.

Ong, H.L. dkk, 1981 Mineralogi. Laboratorium Mineralogi, Departemen Teknik Geologi ITB, Bandung.

Rangkuti N., dan Intan S. Fadhlan M., 1993 Tembikar Tradisi Sriwijaya Di Kayu Agung. SRIWIJAYA dalam perspektif arkeologi dan sejarah. Pemda Tk. I Sumatera Selatan.

Shepard, Anna O., 1965 Ceramics for The Archaeologist. Washington: Carnige Institution of Washington Pub.

Soegondho Santoso, 1993 Wadah Keramik Tanah Liat Dari Gilimanuk dan Plawangan: Sebuah Kajian Teknologi dan Fungsi. Disertasi Bidang Sastra, Universitas Indonesia. 
Soegondho Santoso, 1995 Tradisi Gerabah Di Indonesia: Dari Masa Prasejarah Hingga Masa Kini. Jakarta : P.T Dian Rakyat.

Sudiono, 2000 Laporan Penelitian Bidang Arkeometri: Lokasi Sumber Bahan Baku Gerabah Tejakula Kajian Lingkungan. Jakarta: Proyek Peningkatan Penelitian Arkeologi. tidak terbit.

Utomo, B. Budi, 1988 Permasalahan Umum Arkeologi Jambi. REHPA III, Pandeglang, 5-9 Desember 1986, Puslit Arkenas, Depdikbud.

Wibisono, S., 2000 Terakota Masa Klasik. dalam buku 3000 Tahun Terakota Indonesia: Jejak Tanah dan Api. Museum Nasional Indonesia, Jakarta.

William, Turner \& Gilbert, 1954 Petrography. San Fransisco, W.H. Freeman \& Company.

Catatan:

Penulis mengucapkan terima kasih kepada Ibu Dra. Naniek Harkantiningsih, yang telah memberikan ïin untuk menganalisis gerabah-gerabah dari Situs Leran, Gresik, Jawa Timur serta mempublikasikannya. 